\title{
THE STATE OF POLITICS, GOVERNANCE AND DEMOCRACY IN NIGERIA
} https://doi.org/10.47743/jopafl-2021-20-07

\author{
Afonughe Irikefe OMAMUYOVWI \\ Department of Political Science, Faculty of the Social Sciences, Delta State University, \\ Abraka, Nigeria \\ afonughegoodluck@gmail.com
}

\begin{abstract}
Over the decades, there has been a recurrent and sustained argument that the Nigerian State, like its counterpart in African and other countries of the developing world, under performs due to lack of state capacity to deal with the contemporary complexities of governance. This paper examines the state of politics, governance and democracy in Nigeria and asserted the factors militating against, the promotion of public goods and effective service delivery in Nigeria. As government is about service delivery in continuity and contingency not negating the pivotal state and the cardinal force of politics as the contraption of both elements birth or gives an expressive definition to the institution of a state as a human entity or society. The article draws data from secondary and primary sources, which include the author's close observations of events in Nigeria Governance, politics and political parties while secondary sources entails journal articles, textbook, newspapers including published and unpublished text. The study observed in Nigeria that politics have been driven by self interest and other primordial tendencies which take priority over that of public interest. As it is smiling to mention that democratic government is adduced to be the widely accepted system of government among other form of government; it is accepted because it gives political sovereignty to the people were their will, aspirations, needs and demand are supposed to be guarantee by the state which is the coordinating system that stand as the tool of instrument to encompass all interests within it. The study enunciated that the Nigeria state is challenged with multifaceted challenges such as crisis of governance, utility and deployment of state power, state and management of security among other attendant problems. The paper recommends state reform across the Nigeria; national interest should supersede individual one, emergence of young politicians who are enthusiastic and competent.
\end{abstract}

\section{Introduction}

Nigeria has a country is regarded as the giant of the African continent with her large population as well as good land mass area laden with numerous natural resources. As a state that enjoys such pride among comity of nations within the continent, much is expected in her leadership role of maintaining and practicing the tenets of democracy to the letter, where there exist the indices of sustainable development, good governance, security and piquant government. However, despite are enjoyed position it is not mean to mention that the country is bedeviled with several strands of attribute that keep receding the system which posit that there is mileage between its vantage position and the empirical reality. This again has consistently caused a reminiscent in the mind of people, country and nations within the continent on the causative factors that continue to put the country in sorry state even after over fifty years of independence as a sovereign state in the world. 


\section{The concept of state}

The concept of state could be traced to the two main traditions, the Weberian(weber, 1964, and the Maxist (Marx and Engels 1852/1958). For Max Weber, a state is a human community that successfully claims the monopoly of the legitimate use of physical force in a given territory. The emphasis here is on the claim to the monopoly of the use of force indeed, Weber saw the state as institution existing to safeguard and regulate the society Marxist reject the position of the liberal theory that the state is basically neutral and stand aside to mediate the contradiction inherent in the society (Best, 1990). The state is however, regarded as a product of social system characterized by class contradictions, struggles and class domination. It is a specific modality of class domination as mentioned in (Ake, 1995). In the communist manifesto, the state are construed as an agent of the bourgeoisie, thus the executive of the modern state is a committee for managing the common affairs of the bourgeoisie. The state as a human institution is identified with other broader concepts such as:

\section{Polity}

This is known to be the biggest political entity with its own autonomy. In a polity there is government created and entrusted with the legal recognition and power to rule over the terrain and populace under its control. In its operation there exist hierarchy and administrative control (Paul, 2014).

\section{Polis}

The term polis is said to be political entity that is typical to the ancient and classical Greek civilization during the fourth to the eight centuries which is connected to the community of humanity in a determinate geographical jurisdiction. The polis in this sense was not just a society out was attributed and affiliated with transgenic rational lastingness and a trans-family identity, where members of the community feel a sense of solidity transcending among all ties of blood (Akpatu 20210)

\section{Polity}

Polity is known to be the biggest political space with his own autonomy. In a polity, there is a government created and entrusted with the legal recognition and power to rule over the terrain and populace under its control (Oweii, 2016). It has operational etymological indices such as hierarchical echelons and control of administrative structures that are measured or observed.

\section{Empire}

The term empire can be described as a group of states that are widely governed by a monarch, oligarchy or a powerful sovereign state. An empire is formed when one powerful state is able to extend power beyond its boundaries to govern other states who in this case are not autonomous in their one (Okpetu, 2017). Here, the governed states are regulated by the policies of the superior state. The superior state becomes a hegemony that has the capacity and ability to widen it hegemonic measures over the America space (Ayala, 2015). 


\section{Government}

This refers to a group of people that form an administrative and managerial bureaucracy for the purpose of controlling state apparatus in a particular point time (Onokpauna, 2018). A state exists or is well galvanized through the formation of a government. It becomes an institution responsible for the continuous succession of diverse government or regime.

\section{Nation and national state}

A nation is a population of people who are bound together by common culture, history, religion or tradition and atypically concentrated within a specified geographical reality or religion. However, a nation-state is basically bound together by a culture that is common among its nation (Israel, 2010).

\section{Statehood, stateness and sovereignty}

According to Zaytsew (2016) a state is a polity typology which is basically categorized by two fiscal parameters namely statehood and stateness. Statehood refers to the scenario where individual states are being recognized as unit or its own on the global scene while stateness refers to the concert of nations. Examples of such concert areunited nations organization, European nations and many more (Okpula, 2019)

However, sovereignty refers to its ability to maintain itself without external control or mastery. It is unsurprising when Ari, 2010 refers to it as the source of liberties and rights to its people.

\section{Bureaucracy}

The state apparatus is run by a bureaucracy of officials. It is a social mechanism that maximizes efficiency in the administration of benefits in the state in terms of merit (Power, 2014).

\section{Geographical location}

A state can occupy any place be it an Island, Peninsula or an entire continent (Agbafe, 2001)

\section{The concept of politics}

The changing nature of politics makes, it intricate, complex and more difficult than the physical sciences. This is due to the changing nature and the complexities of man. However, the noun word politics is derived from a Greek word polis which means citystate. The in habitants of the city state are naturally citizens (kepedi, 2013). No wonder politics is essentially a struggle a battle and an attempt to establish order and justice it is in this light that politics can be seen from the subjective idealism or an ideal philosophical concept and existential which is the view from the point of reality. This connect that, politics cannot be separated from the real political world. In the word of a Danish philosopher popularized by Sarte (1905) it is an indifferent and hostile world. This statement was corroborated by Aristotle (384-322 Bi) when he observed that man by nature is a Political animal and by this he meant that the essence of social existence is politics and that two or more men interacting with one another are invariably involved in a political 
relationship. This is so because man from time immemorial prefers social companionship to isolation. Several proponents conceptualized the term of politics as follows.

Harold Laeswell (1937) in his famous book politics defines it as being concerned with that get what, when and how. He attempt to expand the horizon of the enquire to look for politics in many other social settings other than formal public government. It helps underline the fact that politics is about decisions made by people concerning certain objectives which they considered desirable. Harold Laeswell in his definition lays emphasis on, the role of power in the distribution of scarce resources.

According to David Easton in his political system (1953) surmises politics as a process through which binding decisions on the distribution of scarce values are made for a society in a world of change. It is in this light that he views politics as the authoritative allocation of values in an organized society thus, Easton examines the relationship between what goes into the system as demand and what comes out as decisions. In the understanding of Ola (1995) it is dealing with power, to him it is the management and administration of power within an existing nation state and community which is an aggregate of people with shared boundaries, values and some mutual interests, feelings and behavior. From a pluralist perspective, politics involves competitiveness between a variety of interest group each pressing for its own advantage. Since no one group is seen to be dominant politics is therefore a business of bargaining and compromise. However the liberal and Marxist view of politics shall be extricated in the works in relation to their biography.

\section{The liberal view on politics}

The leading exponent of the liberal view of politics is max weber the German sociologist and social historian. Weber was born in 1864. His father who came from a family of textile manufactures in western Germany who was a well-to-do Lawyer and national liberal Parliamentarian in the Germany of Bismarck (Agbefe 2001). His mother was a woman of culture and piety whose humanitarian and religious interest were not shared by her husband, He spent most of His life in his present home a meeting place for both prominent liberal Politicians and celebrated Professors from the university of Berlin. After completing school in1882, he attended the University of Heidelberg as a law Student. A year later at the age of nineteen he went to Strasbourg to save his year of military training and returned to the army for brief period of military exercise in 1885, 1887 and 1888. After two more years at the universities of Berlin and hottingen, he took his examination in-law in 1886 while continuing his studies at Berlin .His independent academic work began in the fields of law and legal history. After completing his dissertation he started the in-service training required for the German bench or bar. During this training he became acquainted first hand with the social and political problems of the agrarian society in the east province of the Elbe river. At the same time he began a study of legal institutions which was formally to qualify him as an instructor in law at the University of Berlin (Arthur, 1930). However, while completing this dissertation, he prepared himself for his duties as an privaldozent in Roman, German and commercial law at the university of Berlin. He also undertook an extensive investigation of rural labour in the German provinces east of Thelma, which led to the publication of 900 page volume in 1892, besides instigating the stock exchange. In 1852, besides investigating the stock exchange, In 1893 he married Marianne Schnitger and at least left his parents' home. In the fall of 1894 he became a full professor of economics at Frciburg University of Heldeberg. In the fall of 1897, when he was thirty 
three, Webar fell ill and was forced to reduce and finally suspend his regular academic work. For four years, he suffered from an acute state of exhaustion and anxiety even small diversions proved too tasking to him at times and this apparently vigorous man would sit for hours at the window staring into space. After almost four years he seemed to recover gradually and resumed his habit of omnivorous reading. Some of it was concerned with the history, organization and economic activities of the medieval monasteries. In 1904, he accepted an invitation to visit the United States and participate is the congress of arts and sciences held in connection with the world's fair at St lousis. In the same year, the first results of his resumed scholarly activities were published such as. An Essay on methodology A discussion of Agrarian Policies in Eastern Germany, the protestant ethics and the spirit of capitalism In 1918 he became a consultant to the German Armistice commission in versalities and to a commission changed with the responsibilities of drafting the Welmar constitution. in the summer of that year, he also taught at the University of Vienna and in 1919 he accepted an offer from the University of Munch. In June 1920, he died of Pneumonia at the age of fifty-six. Pointedly the Liberal view of politics is centered or power which they conceived as the manner gets what they want even in the face of opposition. Upon this fact that max weber (1920) defines power as the degree to which they conceived as the manner in which people get what they want even in the face of opposition. Upon this fact that Max Weber (1920) defines power as the degree to which people gets its own way in a social relationship.

Here, power is a social relationship held in relation to others. So power drives politics, further more Weber gleaned power as the chance of a man or a number of men to realize their own will in a communal action even against the resistance of others who are participating in the action. From the weberian preposition of power we can succinctly eulogize the tenets of the liberal view of politics as follows:

- Recognizes the importance of the economy but does not give it the deterministic role, rather a diverse interest roles were acknowledge

- Power Engineer politics: politics is human activities that are directed towards and indeed reflected in the process of acquiring, using and maintaining power.

- It is the sum totality of all these activities that are harvested toward determined public policies and the means of implementing such polices

- Politics are these interactions through which values are authoritatively allocated for the society

- Politics symbolize the acquisition and utilization of power

\section{The Marxist view on politics}

This school of thought has strong horizon to karl max who was born at Treves in Germany in 1818. The son of a Jewish Lawyer who later became Christian, he got involve in political activities early in his life. In 1848 the year in which there was serious revolt in most of the kingdoms of Europe, Max publicity urged the people of cologne should not pay the taxes imposed upon then by the Prussian government for which he was tried for sedition but acquitted by the jury. Later he was expelled by the authorities when upon he came to England where he lived and still preoccupied himself with politics and write political writings until his death in 1883 (Marxist 1863 Das capital). In his work the communist manifesto (1848) with Engels they all concerned themselves exclusively with one or another aspect of what was called politics. Though Marx spent all his life in political 
activity, for him economic was the basic factor or drive to politics. So, human history exists in the principle of class and exploitation. The Marxism understanding of politics is hinged on his sense and visions on society and the individual. For him:

- Economic Drives Politics

- Politics is a secondary affair due to his believes that its revolution is determined by economics. Economics governs everything such as religion, morality and politics.

- Politics is an activity that is very secondary to the fundamental necessities of living to wring personal security from scare resources. Politics is a conflict of interest arising from difference in the orientations and attitudes from political struggle which arise from conflict among classes and social change.

- Political conflict will only cease with the elimination of the market and of classes in the society.

\section{Politics of the Nigeria State: A Phisique}

The Nigeria State as an entity can be traced to the colonial administration of the Northern and Southern protectorate in 1914 where both entity were contrapted as a simple while for the purpose of administrative convenience and rulership to the 400 of the indirect rule in 1900 (Eregha, 2008). This period witness the fragmentation of Nigerian into certain Sub-divisions which involves the crown colony in the place of Lagos and Calabar and the protectorate referring to other region s of the country. The institutionalization of imperialism principle was used by the British to protect their Metro-politan interest (Toyo, 2002). However, the period of nationalist movement witnessed intense class struggle between the dominant indigenous social class and the metropolitan bourgeoisie which entails the battle for the control of state apparatus. Thus after independence the character of the of the nationalist leader began to show in them particularly when they began to assume position, no wonder Fandakinte (2010) opined that they appear not to bother themselves about the abject conditions of their people and the inherent injustice which colonialism has created in the societies. The petty bourgeoisie now in position of political authority focused more on relations of distribution and were more desirous of imbibing the life style and priviledges of colonialism than in abolishing in justice and oppression of the Nigerian State (Ekekwe 1986). Thus at independence the common enemy was eliminated and the masses were confronted with an indigenous ruling class which was content to inherit the colonial economy with no aim of re forming it.

Also, at independence Nigeria began to evolve a political class that was made up of those who took over from the colonial state hierarchy. Members of the class were made up of western capital agents who came to power to execute policies that were necessarily geared towards promoting the interest of the metropolitan bourgeoisie. This gave rise to the capitalist forces (Drake, 2010) This is led to a crisis of nation-building characterized by hegemonic struggles for access to power at the center and the birth of the 1979 constitution which was a watershed experience in Nigeria's constitutional development, the subsequent party politics that emerged was not much different from what existed in post- independent Nigeria. Political parties were formed along ethnic lines, while the political class politicized the ethnic divides. Invariably what ensued from the symptoms of in competence, ignorance and corruption was politics of bitterness and winner takes all rather than politics of tolerance. The Nigeria State witness further crisis relating to revenue 
allocation, state creation, civil war, power-sharing and coup d'etat that almost led to the disintegration of the political entity (Omoyibo2020). Since then, Nigeria has been bedeviled by claims of marginalization, separatist agitations, resource control, intercommunal conflicts and insurgency. Terrorist attacks and rejection of the Nigerian state have become new threat to the co-operate existence of the country. It was perhaps the need to arrest some of these crises, promote national unity and command loyalty of all that led to the Federal character principle and the quota system as affirmative action to ensure a sense of belonging and loyalty to the federation. Thus, the Federal character principle demands that government activities and institutions must, reflect the diverse ethnic groupings that constitute the geographic expression called Nigeria (section 14, 1999 constitution) unfortunately, the reason for enacting this principle was defeated as the dominant and ruling classes distorted its, use for selfish ends. The principle enabled them to sponsor candidates to high political positions, increasing their influence and undermining the spirit of the principle. According to Eze (2009) invariably, policies, programmes, ascendency to position of power and influence, wealth and security were determined by a few individuals that re-cycled themselves or their relations and children into power and position of authority in a patron-client relationship as government business and activities became personalized, laws became personified and dissent opposition to policies and power then became suicidal as the Nigeria state became privatized (Ivie,2020). That the character of the Nigeria state is worrisome is not in doubt as over fifty years of political independence the country is still reeling from vociferous and sometimes violent challenges to its power and hegemony in various parts of the country particularly in the East, the Niger Delta, the west, the middle belt and the North East where insurgency and terrorism is ranting led by Boko-haram. After over fifty years, the country today is more insecure, less stable and less confidence than it was at independence in spite of the billions of dollars earned from the sale of crude oil and gas. The citizens are on a daily basis assaulted, maimed or killed by either the police or armed robbers and assassins visited with sectarian crisis that the state appears incapable of resolving decimated by the scourge of poverty and ravaged by bribery and corruption is low and high places. The citizen's agony is compounded by the lack of basis infrastructure such as motor able roads, electricity and portable water as well as other basic amenities which are taken for granted in many other countries (Vanguard Newspaper, 2020)

\section{Political Parties and Democratic governance in Nigeria}

The character of the state and its polities is core to understanding the performance of the leadership of political parties and democratic governance in Nigeria. Democratic governance in the first republic was largely plague by political corruption, cleptocracy and nepotism democratic governance by political parties was characterized by the sacrifice of governance and nation building on the altar of ethnic, parochial and personal interest (Aliu, 2013:39). The conspicuous mobilization and manipulation of ethno-religious sentiment to acquire and consolidate state power and ensure economic control were major attributes of political parties and politicians of the first republic (Selotu, 2005). This development, partly resulted in the unhealthy rivalry and tension among Nigerians and the dangerous conflagrations that enveloped the first republic as exemplified by the 1902 and 1963 census crisis (Omodia, 2013). Thus, democratic governance as steered by political parties in the 
second republic started october1 1979 and marked the termination of the January 15, 1966 military intervention in Nigeria in politics. The failure of democratic governance to enhance the delivery of public goods and services and promote societal peace and stability dominated national discourse copiously, Nigeria have to cope with the problems of ineptitude on the part of the political leadership, widespread political corruption, identity based politics, massive electoral malpractices as well apolitically motivated violence until the overthrow of the second republic by the military (Ogundiya, 2009). Thus, the annulment of the June 12, 1993 presidential elections caused another setback to the whims and caprices of democracy in Nigeria because it could have cemented the smooth transition to legitimate governance.

Upon the emerge of democratic governance in 1999 there was great expectations of hope, accountability, transparency, popular participation and in improved economic wellbeing of the people (Aliu, 2013:39) . The high hope expresses by most Nigerians was borne out of the recognition that in the previous republic, democratic governance was mismanaged by political parties and the ruling elite with a great blight on the quality of governance, economic development and welfare of the people. In this republic the media, civil organizations seems to enjoys greater freedom and liberties. The legislature as the basking bastion was highly regarded (fashgbeya, 2010). This experience gave room to some degree of checks and balances in governance (Ibe, 2014), it is smiling to mention that the spectacular regime of Olusegun Obasanjo led to the wide use of the global system for mobile communication, new salary scale for civil servant and the debt rules secured for the country. Other attendant success are the passage of freedom of information bill,respect for the rule of law, establishment of nine federal universities and the deregulation of the downstream sector by preceding administrations(Igba,2021). Despite these cardinal achievements, political parties and leadership are still fraught with weaknesses which evolve from persistent shortage of food, employment, security, portable water, accessible healthcare, road. The widespread manifestation of insecurity in the form of armed robbery, kidnapping, banditry and insurgency explain the precarious state of the country (Omtola, 2008). It is of this view that Ikelegbe (2020) enunciated some of the visible problems of Nigeria governance in Nigeria which entails:

\section{Crisis of governance}

The Federal government approach to governance in recent times has been described as slow, inactive and reactive. For example, herders attacks and associated atrocities have not had concerted state response, as the perpetrators are hardly arrested and prosecuted. There is a sense of Federal government tolerance, inaction and in attention which have been reinforcing impunity and expansiveness with which the crimes are conducted without any form of punishment. Freedom house report (2020) on freedom and democratic trends in the world rank Nigeria as partly free but is one of the seven countries in Africa that have experienced notable decline in democratic governance and respect for human rights.

\section{Utility and Development of State Power}

Governance is increasingly concentrated in a few aides to the president popularly known as cabals whose composition, interest and goals seem to be narrow and identity based. Federal character, balance quota-system and equity love been thrown to the wind. 
The State and the Management of Security

Conflict, violence and criminality have been in the rise and increasingly households are becoming exposed to violent incidences including crime, cultism, resources dispute, communal and religious conflict and terrorism (World Bank \& NBS 2018)

\section{Conclusion}

Nigeria as a country is faced with national identity crisis where her citizens are like orphans that are left to the fate of the society. These challenges have leadership crisis as it main precursor. And a state that cannot perform its primary responsibility of security to its people has lost her internal and external sovereignty where citizens are naturally forced to return to brute force in the place of civility.

\section{Recommendations}

- There should be state reforms across the Niger. Reformation should begin from the basic cradle of leadership to the apex.

- National interest should supersede individual interest

- $\quad$ There should be an emergence of the young ones who are patriotic and competent that may be able to champion national and populist courses.

- There should be sincere conceptualization of leadership and development in Nigeria

- The character and values for modesty should be recapitulated in every hook and cranny of the nation.

\section{References}

1. Ake, C(1996), Democracy and Development in Africa Ibadan Spectrum Books.

2. Akpata, I (LOLO). Democracy and the crisis of Governance in Nigeria AkpatapubishersOwei.

3. Agbefe, E. (2001). An Introduction to the methodology of political science. COEWA consult publisher.

4. $\quad$ Ari, A. (2010). Nigeria and its people.Pius Publishers.Ughelli

5. Aliu, M. (2013). Legislative corruption and Democratic consolidation in the Nigerian fourth Republic Journal of sustainable Development in Africa Vol. 15 No 6, 2013.

6. $\quad$ Ari, V. (2010). Nigeria pro-democratic Nation. Ari publishers. Ilesha

7. Arthur, M. (1930). The Iron cage, An Historical Interpretation of Marx Weber

8. Ayala, Y. (2016). Nigeria Democratic Era. The journey monograph Grape ville publishers. Lagos

9. Best, V. (1990). Nigeria and indigenization. An outlook Victor Publishers ogun

10. Dake, M. (2010). Political sociology for a Globalizing world. Cambridge polity press.

11. Ekekeve, E. (1986) Class and state in Nigeria London Longman Chicago.

12. Eregha, E. (2008) West African Colonial policies Eregha publishers Ughelli.

13. Eze, O. (2009) Interrogating the National Interested Nigeria's foreign policy in EzeOsita (Ed) Beyead 50 years of Nigeria's foreign olicy. Issue challenges and prospects, Lagos. Nigeria institution of International Affairs.

14. Fashagba, J. (2009). The Roles of the committee system in Enlacing legislative efficiency in Nigeria. The case of Kwara State house of Assembly Journal of sustainable Develompment in Africa 10(14) - (26 44). 
15. Fadakinte, M (2010). The state a conceptual Jungle? Journal of Alternative perspective in the social sciences

16. Freedom House (2020). Freedom in the World Report. Freed House. Orglarticle/democratic trends Africa for charts retrieved 13/6/20.

17. Harold, L. (1958) Politics. Who get what, when, it meridian, Newyork.

18. Ibe, N. (2014). The Nigeria State.Republic publishers Ogun.

19. Igbe, A. (2012). An Assessment of Dividend of Democracy in Buruku Local Government Area of Benue State Nigeria. A BSC Poject submitted to Department of sociology, AhmduBelllo University Zaria, Nigeria.

20. Ivie, Y. (2020). THE Receding State of the Nation State Eleme publishers.Eleme.

21. Ikelegbe, A. (2021). The Emerging Ruptures of the State.A persective on the Nigerian crisis.A monograph.

22. Kpedi, F. (2013). Nigeria and the Colossal Resources. Nukpedi publishers Warri.

23. Karl, M. (1983). Medical Impressions of Karlmae.

24. Marx, K. and Ergels, F.(1983). Socialism.progress publishers Moscow.

25. Ogundiya, I. (2010). Corruption.The Bane of Democratic stability in Nigeria current. Journal of social sciences (2) (4): $233-241$.

26. Omodia, S. (2013) Governance and threat to National security in Emerging Democracy: A focus on the Nigerian fourth Republic. Research on humanities and social sciences, 3(4) 36 - 42.

27. Omotola, J. (2008). Democratization, Good Governance and Development in Africa the Nigerian experience. Journal of sustainable development in Africa Vol. 9, 2008.Agettevile.

28. Omoyibo, P. (2020). The problems of political parties and the crisis of Governance in Africa.codestria publishers.

29. Okpetu, E. (2017). The Art and craft of leadership: An out look. Von publishers Ibadan.

30. Okpala, C. (2019). Humility, forgiveness and love.The Heart of Ethical Stewardship. North Carolina A\&T State University.

31. Seleotu, D. (2005). The challenges of leadership and Governance in Nigeria in S. Odion Akin (ed) 32. Zaytsev, N. (2016). Determinants of the policy impact of Analytical communities. Russian Regions: cases of Kandia, Tatarstar and Saratov. Doi. https://dri.org/10.1515ices.2016.0033. 